\title{
Building social capital with skills transfer in the writing center at American Design University in Qatar
}

\author{
Molly McHarg \\ Virginia Commonwealth University, Qatar
}

\begin{abstract}
This study examines English faculty perceptions of the Writing Center at American Design University in Qatar (ADU-Q) through a social capital analysis. This was part of a larger study that took a sociocultural approach to English faculty perceptions of writing center work at ADU-Q. One of the emergent themes in that study was the lack of students' language skill transfer from English courses to their disciplines. This finding has critical implications for the development of writing center and writing-across-the-disciplines work by uniting the fields of Composition, TESOL, and writing center research.
\end{abstract}

\section{Introduction}

This study stemmed from my own experiences as a writing center ${ }^{1}$ instructor in Qatar. For over nine years I have worked in a number of different American higher education branch campuses in Qatar; inevitably, I have spent much of my time 'marketing' in an attempt to get students to visit the various centers. Research has indicated that faculty support can be beneficial to encouraging student visits to the writing center, which, in turn, can lead to positive educational development, particularly with language learners(Williams \& Takaku, 2011). Therefore, my study began with my exploration of English faculty perceptions of the Writing Center at American Design University in Qatar (ADU-Q), a higher education institution which prepares students for disciplines such as fashion, graphic, and interior design. One of the emergent themes from this study was the consistent lack of transfer of languagerelated skills from English classes to the disciplinary-specific requirements in the design field. Lack of transfer, which suggests that students are unable to carry over skills learned in one discipline to another, has led to faculty frustration in all disciplines. Excerpts from interviews with English faculty members and the Writing Center Coordinator demonstrate a clear need to improve this issue. Furthermore, both groups identified this as a task in which the writing center could play a facilitative role, making it an ideal source of internal marketing for the writing center's services.

The unique, rapidly evolving sociopolitical context of this research site lent itself to a rich investigation of faculty perceptions. The socio-political background in Qatar influences education policies that are then incorporated into ADU-Q's institutional directives. These converging, and sometimes conflicting, policies at the intersection of local Qatari culture and American higher education mandates have been, and continue to be, a source of challenge for institutions in Knowledge City ${ }^{2}$. The following section will provide an overview of the key social, political, and cultural considerations that play a role in ADU-Q's instructional delivery, as well as some of the factors that may influence faculty perceptions of the Writing Center. 


\section{Context}

\section{Present day Qatar}

The past ten to fifteen years have witnessed an explosion of American higher education institutions in the Arabian Gulf (Hamdan, 2013; Kane, 2011; Mills, 2009). Qatar alone is currently home to seven American university branch campuses, with more being added each year. All of these university branches were established with the expectation of replicating the home campus in the United States in every aspect - in fact, one of the key features is that students who graduate from these branch campuses will receive an identical degree that is indistinguishable from that awarded on the home campus (i.e., there is no identifying language that indicates a student ever spent time in Qatar) (Kane, 2011; Mills, 2009; Wildavsky, 2011; Zoepf, 2005). It is also notable that in Qatar, these universities have been established only by invitation from the Qatari government - in other words, the intent is to convey that their existence in the country should not be interpreted as a type of traditional hegemonic imperialism. Nonetheless, there appears to be a contradiction between the invitation to offer identical education without compromising institutional standards, and the mandate to prioritize local Qatari citizens. It is generally accepted that the local educational system and standards have not traditionally prepared students to enroll and succeed in the American university branch campuses in Qatar(Hamdan, 2013; Khatri, 2011). An evaluation report from Qatar's Supreme Education Council confirms that "performance levels are generally low" and

The longer term picture (examining the results from 2004 to 2008) is no brighter: there is some variability in performance for different grades, subject areas, and years; however, there are no clearcut indications of improvement over time. (Evaluation Institute, 2008, slide 7)

More recent news reports indicate that local Qatari schools continue to struggle with the English language, absenteeism, and more (Khatri, 2013; Walker, 2014). This educational gap again indicates the need for specialized, individualized instruction that writing centers are meant to provide.

Each university in Knowledge City comes with its own services and departments, one of which is a writing or academic support center; these writing centers vary widely in their goals and purposes for serving students. Nonetheless, writing centers in Qatar share a common context: they all deal primarily with English language learners, who comprise the overwhelming majority of the student population. Although there have been numerous publications about why writing centers are important for second language learners(Bruce \& Rafoth, 2009; Fels, 2010; Harris, 1997; Williams, 2002, 2004; Williams \& Severino, 2004), very little attention has been paid to faculty perceptions of writing centers for this population of learners. This study sought to gain a deeper understanding of English faculty perceptions of the writing center.

Furthermore, as a member of the Doha Writing Center Network ${ }^{3}$, it has become evident to me that the phenomenon of ill-attended writing centers is representative of all institutions in Knowledge City writing and academic support center staff often lament that they spend more time attracting students than in conducting tutoring sessions. Syed (2003) underscores this general challenge with motivation ${ }^{4}$ in the Arabian Gulf education when he notes:

One does not have to talk for long with English language teachers in the Arabian Gulf to get a picture of the challenges they are constantly dealing with. EFL teachers in this region have identified student motivation, literacy, underachievement [as problems]. These issues, coupled with outdated curricula and methodologies [...] paint a very unflattering picture of education in the region. (p. 337)

While the curriculum at ADU-Q mirrors what is offered on the home campus in the United States, Syed's observation of "outdated curricula" aligns with the general challenges faced in the K-12 educational 
system in Qatar. Thus, students entering the American branch campuses in Qatar are faced with an entirely new educational endeavor compared with what they experienced in their earlier years.

In contrast to Syed's commentary about lack of motivation for learning, Williams (2002), working within the U.S. writing center context, aptly notes that

second language writers are coming in increasing numbers [to the writing center] and there is no indication that this trend will end soon. (p. 74).

Given that many U.S.-based writing centers conduct much of their work with second language writers who frequently visit, the infrequency of visits by English language learner writers in Qatar is somewhat perplexing. Why do students who have a greater need for English language writing services avoid the writing center? How might English faculty shape students' visitation frequency to the writing center? How can the writing center be seen by both students and faculty as an important and central point of students' education?

\section{Admissions and English curriculum at ADU-Q}

As this study highlights the importance of the writing center and English language learning support, it warrants an overview of the institutional English language requirements and curricular framework in Qatar. All of the universities in Knowledge City are contractually bound to maintain the same high admissions standards that they would on their home campuses (Hamdan, 2013; Wasserman, 2009). Therefore, theoretically, students applying to ADU-Q should be held to the same admissions criteria as the home campus. Nonetheless, attracting and recruiting students of the same high caliber becomes a political and logistical conundrum with the vastly different profile and demographics of applicants - in other words, thus far in Qatar it has been more challenging than in the U.S. home campus counterparts to find adequate numbers of high-caliber applicants. The policy of Qatarization give priority to Qatari citizens in the country; within Knowledge City, contractual mandates also give preference to Qatari applicants at all of the universities, effectively reducing the pool of applicants to consider.

At ADU-Q, all prospective students apply to the undergraduate program through the submission of high school transcripts, standardized test scores, a written essay, and a portfolio of artwork. The writing sample generally carries a small amount of weight in the admissions process; on occasion, if an essay appears suspiciously superior, an applicant may be invited to complete a controlled writing exercise. Otherwise, the other documents of the application dictate whether or not a student receives an acceptance letter. It is also notable that traditionally the vast majority of students accepted into ADU-Q's program are Qatari ${ }^{5}$. These students have typically graduated from the local schools, where education has undergone massive transformation in recent years. This transformation in education has brought about a number of reforms, one effect of which has been students graduating who are less academically prepared because of the instability and ongoing changes. Although these Qatari students receive preference in the admissions process, they are often less well-equipped academically than their international counterparts. A recent New York Times article highlights this phenomenon:

One problem is that many local high school students are not qualified to immediately enter elite institutions like Northwestern or Georgetown, highly competitive schools that typically admit less than one in five applicants in the United States. There are no formal quotas on the number of local students admitted to the Gulf campuses.

To bridge the gap, overseas campuses have resorted to using conditional admissions, bridge programs or foundation years to help local students catch up. In some cases, these extra courses are taught by professors from home campuses who are visiting the Middle East for the first time. (Hamdan, 2013, para 12-13)

McHarg, M. (2015). Building social capital in the writing center by transferring skills at American Design 
This reality of underprepared students is one that emerged as a notable point during interviews conducted in this study and can be related to the lack of language skills transfer from the writing center to other contexts.

\section{Key concepts}

\section{Writing across the curriculum/ writing in the disciplines}

The connection between writing and the design field was made explicit in the article The Process of Design is Almost Like Writing an Essay (Orr \& Blythman, 2002). The authors argue that although art and design studies have typically been viewed as disciplines that reject or remain disconnected from writing principles and practices, in fact, the opposite is true. They conducted research at The London Institute the largest art and design college in Europe -- where they interviewed design students about their reflections on design and writing processes. The interviews led the researchers to the following five focal areas:

the role of peers; conceptions of 3D and 2D; personal relationship with text and design; audience and relation to text; understanding of process. (Orr \& Blythman, 2002, p. 44).

Selections from the students' voices provide concrete evidence as to how, although the acts of writing and design are unique in their own ways, students describe and view them in a very similar manner. The authors also offer practical advice for teachers in these contexts:

For example, it is not uncommon to work with students who do not want to commit words to paper unless they are fully formed. While design students may understand the creative thinking that precedes their designs, these students find it hard to brainstorm for a writing assignment. In this situation, we remind them about the role of the sketchbook in the design process. Sketchbooks offer a place where students can try out creative ideas, some of which will work and will be further developed. (2002, p. 49)

While Orr and Blythman offer a solid and explicit connection between studying in an art and design school and writing, their study was conducted in a context entirely different from Qatar (England) with a different population of students, whose native language was English. This current study builds on their research by further investigating writing in the disciplines in a unique language environment through the lens of the faculty and writing center.

A similarly unique perspective is offered in Yavarow's (2012) column From the Interior Design Studio to the Writing Center: One Tutor's Unconventional Journey to Designing a Tutorial. In this brief article, Yavarow articulates many of the ways in which she views the process of design to be helpful in explaining writing concepts and processes to her peers in writing tutorials. This article reinforces the idea that writing can be appropriately interpreted and situated in a discipline-specific context, such as at ADU-Q. It also highlights the positive and reflective nature that a peer tutor can offer when working with other peers in the design discipline. Yavarow's work is suggestive for those working in other unique cultural-disciplinary contexts such as Qatar, and prompted me to investigate faculty perceptions and connections relevant in my own context.

\section{Social capital}

This article takes a social capital perspective in analyzing emergent themes in the data collection. Social capital theory has its origins with Bourdieu (1986), who based his theories on economics and global social conditions in France at the time. He identified social capital as one type of capital: 
the sum of resources, actual or virtual, that accrue to an individual or a group by virtue of possessing a durable network of more or less institutionalized relationships of mutual acquaintance and

recognition. (Bourdieu \& Wacquant, 1992, p. 119).

The present study explores the possibilities of social capital between English faculty and the writing center at ADU-Q.

Bourdieu's theories focused on socioeconomics and class privilege, which is one relevant component of the Qatari context. For example, Qatari students are granted significant privileges, including free education, stipends for attending school, and often guaranteed employment upon graduation. In this scenario, Qatari students do not need to invest in the development of social capital (at least within the academic context) to supplement their economic wealth. On the other hand, non-Qatari students typically find themselves having to borrow money or prove themselves worthy of financial assistance from the Qatari government; these international students must demonstrate and develop a higher level of social capital. ${ }^{6}$

In contrast to Bourdieu, whose theories have often been considered deterministic, other scholars investigated social capital theory through different lenses. For example, Coleman (1988), an American sociologist who wrote during approximately the same time as Bourdieu, placed more emphasis on the value of social capital for the marginalized and powerless. Non-Qatari students enrolled in higher education institutions in Knowledge City parallel Coleman's idea of "marginalized and powerless", in that they are not entitled to the financial privileges that Qatari students receive. Coleman brought together the fields of sociology and economics and suggested that people had the ability to use the resources available to them in order to become more successful:

Social capital is productive, making possible the achievement of certain ends that in its absence would not be possible. [...] social capital inheres in the structure of relations between actors and among actors. (Coleman, 1988, p. S98)

More recently, Putnam (1995) made a passionate call for the reinstatement of social capital with his publication Bowling Alone: The Collapse and Revival of American Community. He argues that the changing society in America is leading to greater individualism, with less emphasis placed on the importance of social connections and social capital. Although Putman writes from an American perspective, his theories are useful to consider in the Qatari society, where social connections are paramount (Zaharna, 1995). Putnam's theory that social connections should increase social capital raises questions about the Qatari context - is the ADU-Q writing center, a focal point of collaboration and social networking, thriving because of the local context? If it is not thriving, why not? Can the writing center itself develop social capital with the English and disciplinary faculty by achieving goals to facilitate students' transfer of skills across disciplines? The relationship between faculty and the writing center fits neatly within this social capital framework because how faculty perceive the writing center then results in actions that directly affect student visits to the writing center. This study takes a social capital perspective to analyze English faculty perceptions and how these influence and intersect with the writing center's institutional profile.

Social capital and its relevance to writing center work is particularly noted by (Murphy \& Stay, 2006, p. 278):

As we conceptualize 'The Idea of the Writing Center' for this new century, one of our greatest ethical challenges will be to define and actualize the writing center as a form of social capital that can produce aggregate growth within academic and social communities [...] We should also recognize the transformative power of writing center work and seek to envision the writing center as a locus of significant social capital for both the academy and the community.

McHarg, M. (2015). Building social capital in the writing center by transferring skills at American Design 
(Hall, 2007) repeated this call to view writing centers through a social capital framework in his description of a successful Writing-Across-the-Curriculum initiative. Both Murphy \& Stay and Hall cite Putnam's recent contributions to the field of social capital, whereby

social capital is found in social connections, from which emerge the most significant types of networking and interpersonal relations that are the basis of community formation. (Murphy \& Stay, 2006, p. 278)

\section{Methods}

This article stems from a doctoral research project; the initial study set out to answer the following primary research question: What are English faculty perceptions of ADU-Q's Writing Center? A number of ancillary questions were also posed in an effort to fully capture participants' varying experiences and expectations. The study explored these perceptions through a sociocultural framework by asking questions about participants' backgrounds, experiences in Qatar, work with students, and interactions with the writing center. Interviews were semi-structured; the interviewer began with a general base of questions, but often supplemented or modified questions throughout the interviews. Data was collected and triangulated with three primary sources: 1 ) interviews with English faculty, 2) interviews with the Writing Center Coordinator, and 3) archival documents, such as tutorial session reports. Data was coded with an open-ended methodology and analyzed with NVivo software. All names used are pseudonyms.

In all, seven English faculty members and one Writing Center Coordinator were interviewed. They all hailed from North America, and only one had advanced proficiency in the Arabic language; the rest had minimal or no Arabic language proficiency. Their time at ADU-Q ranged from 2-14 years, with an average of 8 years. They had all received degrees in English at Masters level; specializations ranged from creative writing to technical writing and poetry. Notably, none specialized in TESOL (teaching English to speakers of other languages).

As a consequence of the exploratory nature of the above-mentioned study, the results yielded emergent themes; one of these themes was the notion of lack of language skills transfer between English classes and the disciplinary-specific design courses. Results related to this theme are presented below.

\section{Findings}

The most common refrain from English faculty about how their work connects with a discipline-specific institution was that of the lack of transfer from English classes to other classes. Bob put it simply by saying:

the students struggle with making their education interconnected. Like actually seeing the relationships and some of the overlap and some of the similarities among these different disciplines that they're getting.

Lucy also commented:

I do wish they went to the writing center more for their design courses than I hear and can tell that they do; and not just think of it as something that I do when I'm taking an English class. For a number of years, [when] students would come to me with a paper for a design course, for me to talk with them about, [...] I noticed that the transfer of skills was not happening for them. And a lot of it had to do with their own motivation. Their idea was: “Now I'm in a design course, I don't have to worry about English class-type requirements". And it might not be verbalized exactly that way, but that's what was going on in their thinking. And you could tell that we were getting much better 
papers from them than their design faculty was getting. So [...] I have thought at times that I wish that they would use the writing center for their other classes. More than they do.

In acknowledging this lack of transfer, Francis suggested that this might be an appropriate role for the Writing Center to further encourage:

I've heard from all the disciplines that they have difficulty transferring all different kinds of skills back and forth. I don't know how the writing center can help that, other than the fact that we see what they do in the English class but they come to you in other contexts too, so you can kind of remind them of things.

Zoe also alluded to the idea that this disciplinary transfer of skills might be an appropriate role for the Writing Center:

The role of the writing center, I think it is to work with the students all the way through from freshman to their senior year so that there's a relationship that's developed, and that it goes across the curriculum; so it's not just in their English classes.

Effectively teaching the transfer of skills in first-year composition courses has been a key challenge in composition studies for many years. Wardle (2007) laments the fact that there is such a dearth of scholarly research studies to investigate this challenge:

Although there have been a few theoretical discussions of writing transfer and FYC [First Year Composition] (Foertsch), writing centers (Hagemann), and advanced writing courses (Kain and Wardle), nearly all research studies of writing-related transfer are confined to the field of professional communication. Composition researchers have conducted only three case studies (McCarthy; Walvoord and McCarthy; Carroll) that discuss FYC writing-related transfer problemsand these were not studies initially or primarily interested in transfer. $(2007$, p. 65)

Julia further commented in her interview that this lack of transfer also indicates a common misperception about the role of English faculty and the abilities of language learners in the classroom:

I think sometimes there's a misunderstanding of the role of the English department and the role of the Writing Center in a discipline-specific school, that we're all seen as service in a way. [...] I think in some cases there's not a lot of understanding in the way that service works; that English is a skill - if you're a native speaker or if you're an ESL speaker - that has to be developed [and] practiced in order for it to stay strong, and so they might be able to write really well. This is something that [name omitted] and I have talked about a lot, because it seems like every sometime of the year this comes up as a huge issue with our students not being able to write in the design classes and why can't they write. But I think there needs to be an understanding that they spend a lot of time in design classes and they spend a fifth of that time in the writing class; so if they're not getting good writing behavior modeled for them, they're probably not going to think it's that important. And I think that's not the fault of the focus discipline school, it just falls out [in] that situation; so I think it's important for all of us to work as a collective and try to explain the importance of writing.

This theme of problems with transfer from English classes to disciplinary courses emerged from both English faculty and the Writing Center Coordinator. The Coordinator's voice reinforces the English faculty viewpoint:

possibly the problem is that the students separate these skills and identify them as English skills, and they don't transfer them into writing a paper in the [name of department] or spelling things correctly in graphically designed posters. That's probably the biggest problem that I see...

The lack of transfer of skills is clearly a key issue for English faculty and Writing Center staff, which could yield stronger social capital for the ADU-Q Writing Center within the entire institutional context. 
It should be noted that this study focused solely on the relationships, collaborations, and perspectives of English faculty and Writing Center staff. Future research is needed to account for other stakeholders, especially the students and faculty members in other disciplines. Students play an active and critical role in the institutional social capital, and their experiences, perspectives, and motivations are paramount to appreciating the broader picture and analysis of these issues of skill transfer. This study yielded conjectures and anecdotes about how faculty in the art and design disciplines feel about students' transfer (or lack thereof) of English skills. Additional research could provide an opportunity to hear the voices of these disciplinary faculty members and their opinions of how students can and should be supported by the writing center, by English faculty, or perhaps by other support services not yet considered in this study.

\section{Conclusion}

This study examined English faculty perceptions of the Writing Center at American Design University in Qatar (ADU-Q) from a social capital perspective. Findings suggest that a more proactive approach to teaching students to transfer language skills may be beneficial for both the students and the faculty, thereby boosting the social capital of the writing center. For example, if grammatical accuracy is of great importance to the English and design faculty, the Writing Center can be the place where this reinforcement of grammatical accuracy takes place. The Writing Center's discretionary role in prioritizing student needs suggests an inherent power hierarchy over students; however, writing center pedagogy indicates that one-on-one tutoring should be highly student-centered and dictated by the student's own learning priorities. This discrepancy between currently accepted best practices in writing center work and the practical application of tutoring that would lead to improved social capital within the institution and amongst faculty is one that also lends itself to future research. In places where there are such evident and easily identifiable challenges, such as the lack of transfer, should writing center professionals develop new practices and procedures that proactively address these areas of learning? Or should writing center pedagogy remain unchanged and continue its mantra of allowing students to dictate the tutoring session agendas? It is hoped that these preliminary findings will serve as a launch point for improved programming of the ADU-Q Writing Center, as well as serve as a basis for future research at higher education institutions in Qatar and around the globe.

\section{References}

Abrar-ul-Hassan, S. (2009). Learner motivation in language teaching. Compleat Links, 6(1). TESOL International. http://www.tesol.org/read-and-publish/journals/other-serial-publications/compleatlinks/compleat-links-volume-6-issue-1-\%28march-2009\%29/learner-motivation-in-language-teaching

Bourdieu, P. (1986). The forms of capital. In J. G. Richardson (Ed.), Handbook of theory and research for the sociology of education (pp. 241-258). New York, NY: Greenwood Press.

Bourdieu, P., \& Wacquant, L. J. D. (1992). An invitation to reflexive sociology. Chicago, IL: University of Chicago Press.

Bruce, S., \& Rafoth, B. (Eds.). (2009). ESL writers: A guide for writing center tutors. (2nd ed.). Portsmouth, NH: Heinemann.

Candlin, C. N. \& Hall, D. R. (2001). Teaching and researching motivation. London: Longman.

Coleman, J. S. (1988). Social capital in the creation of human capital [supplemental material]. The American Journal of Sociology, 94, S95-S120. 
Dornyei, Z. and Ushioda, E. (2009). Motivation, language identity and the L2 self. Bristol: Multilingual Matters.

Dwaik, R. and Shehadeh, A. (2010). Motivation Types among EFL college students: insights from the Palestinian context. An-Najah University Journal of Research, 24(1): 333-360.

Evaluation Institute (2008). Qatar Comprehensive Educational Assessment (QCEA) 2008 summary of results. Doha: Supreme Education Council Publications.

Fels, D. (2010). The vernacular architecture of composition instruction: What the voices of writing center tutors reveal about the influence of standardized instruction and assessment. (Unpublished doctoral dissertation). Indiana University of Pennsylvania, Indiana, PA.

Hall, R. M. (2007). A social capital view of a writing center - WAC partnership. Praxis: A Writing Center Journal, 7(2).

Hamdan, S. (2013, March 17). At foreign schools in the Gulf, a more local push. The New York Times.

Harris, M. (1997). Cultural conflicts in the writing center: expectations and assumptions of ESL students. In C. Severino, J. Guerra \& J. Butler (Eds.), Writing in multicultural settings (pp. 220-233). New York, NY: Modern Language Association.

Hashimoto, Y. (2002). Motivation and willingness to communicate as predictors of reported L2 use: the Japanese ESL context. Second Language Studies, 20(2), 29-70.

Kane, T. (2011). Transplanting education: A case study of the production of "American-style" doctors in a non-American setting. (Unpublished doctoral dissertation), The University of Edinburgh, Edinburgh, U.K.

Khatri, S. (2011). Fewer Qataris getting into college, more dropping out, Doha News. Retrieved from http://dohanews.co/post/4278670032/fewer-qataris-getting-into-college-more-dropping-out

Khatri, S. (2013). Qatar's education system grapples with language challenges. Doha News. Retrieved from http://dohanews.co/qatars-education-system-grapples-with-language-challenges/

Kim, T.Y. (2006). L2 learning motivation from a sociocultural theory perspective: theory, concepts, and empirical evidence. English Teaching, 61(4), 51-78.

Kim, T-Y. (2007). Second language learning motivation from an activity theory perspective: longitudinal case studies of Korean ESL students and recent immigrants in Toronto. University of Toronto.

Kim, T-Y. (2011). Sociocultural dynamics of ESL learning (de)motivation: an activity theory analysis of two adult Korean immigrants. The Canadian Modern Language Review, 67(1), 91-121.

Mills, A. (2009, February 20). Academics in the Persian Gulf. The Chronicle of Higher Education, p. B7.

Murphy, C., \& Stay, B. L. (Eds.). (2006). The writing center director's resource book. Mahwah, NJ: Lawrence Erlbaum.

Orr, S., \& Blythman, M. (2002). The process of design is almost like writing an essay. The Writing Center Journal, 22(2), 39-54.

Putnam, R. (1995). Bowling alone: America's declining social capital. Journal of Democracy, 6(1), 65-78.

Qashoa, S.H.H. (2006). Motivation among Learners of English in the Secondary Schools in the Eastern Coast of the UAE. British University in Dubai. 
Robinson, H. (2009). Writing center philosophy and the end of basic writing: motivation at the site of remediation and discovery. Journal of Basic Writing, 28(2): 70-92.

Suleiman, M. (1993). A study of Arab students' motivations and attitudes for learning English as a foreign language. Arizona State University.

Syed, Z. (2003). The sociocultural context of English language teaching in the Gulf. TESOL Quarterly, $37(2), 337-341$.

Walker, L. (2014). Qatar Education Council to tackle rising student absenteeism problem. Doha News. Retrieved from http://dohanews.co/sec-announces-crack-pupil-absences/

Wardle, E. (2007). Understanding 'transfer' from FYC: preliminary results of a longitudinal study. Writing Program Administration, 31(1-2), 65-85.

Wasserman, G. (2009, February 20). Bridging cultures in Doha. The Chronicle of Higher Education, p. B9.

Wildavsky, B. (2011, March 16). Serving foreign students in new ways. The Chronicle of Higher Education.

Williams, J. (2002). Undergraduate second language writers in the writing center. Journal of Basic Writing, 21(2), 73-91.

Williams, J. (2004). Tutoring and revision: Second language writers in the writing center. Journal of Second Language Writing, 13, 173-201. doi: 10.1016/j.jslw.2004.04.009

Williams, J., \& Severino, C. (2004). The writing center and second language writers. Journal of Second Language Writing, 13, 165-172. doi: 10.1016/j.jslw.2004.04.010

Williams, J., \& Takaku, S. (2011). Help seeking, self-efficacy, and writing performance among college students. Journal of Writing Research, 3(1), 1-18.

Yavarow, A. (2012). From the interior design studio to the writing center: One tutor's unconventional journey to designing a tutorial. The Writing Lab Newsletter, 36(9-10), 14-15.

Zaharna, R. S. (1995). Understanding cultural preferences of Arab communication patterns. Public Relations Review, 21(3), 241-255.

Zoepf, K. (2005). In Qatar's 'Education City,' U.S. Colleges build atop a gusher. The Chronicle of Higher Education.

\footnotetext{
${ }^{1}$ Writing centers are a place of academic writing support for students. These centers typically stem from a model in North America, but have recently gained popularity worldwide. More details about writing centers can be found at http://writingcenters.org/.

${ }^{2}$ Knowledge City is an area of Doha that houses the branch campuses of the imported American universities. For a more detailed description of the development of Knowledge City, see Kane (2011).

${ }^{3}$ This is an informal network of writing center professionals in Doha.
} 
${ }^{4}$ Motivation in the Gulf region has long been a popular research topic. Due to the limitations of this paper, student motivation, while an important component of any educational research project in the region, will not be fully explored here. See Abrar-ul-Hassan, 2009; Candlin \& Hall, 2001; Dornyei \& Ushioda, 2009; Dwaik \& Shehadeh, 2010; Hashimoto, 2002; Kim, 2006, 2007; 2011; Qashoa, 2006; Robinson, 2009; Suleiman, 1993 for more details.

${ }^{5}$ Although enrollment was primarily dominated by female Qatari students, admissions have become more international and gender-diverse in recent years. Notably, the newly admitted students in Fall 2012 included only 53\% Qatari nationals.

${ }^{6}$ As mentioned in note 4, motivation is a peripheral, yet important, concept related to this study. See earlier references for motivation in the Gulf and how these theories connect with Bourdieu's theory of social capital. 